\title{
ANALISIS PERBANDINGAN PENGGUNAAN METODE PENYUSUTAN AKTIVA TETAP BERDASARKAN KEBIJAKAN AKUNTANSI DAN PAJAK PADA PROFITABILITAS PT. WIJAYA KARYA (PERSERO) TBK
}

\author{
Puspa Rini \\ Email: puspayovrin22@gmail.com \\ Program Studi Akuntansi, Fakultas Ekonomi \\ Institut Bisnis Dan Informatika Kosgoro 1957
}

\begin{abstract}
There are differences in the provisions according to the statement of Financial accounting standards with the provisions of the Constitution on which regulates the management of fixed assets to determine the amount of depreciation load of fixed assets so that the profit can be achieved by the company of different methods and provisions and can be known to the ability level of the company in generating profitability. This research was conducted to understand the difference in the use of depreciation methods in fixed assets according to accounting and tax policies in creating company profitability. Based on research that has been carried out depreciation expense based on greater accounting policy compared to depreciation load using depreciation method based on tax policy. Resulting in a different profit. This results in a profitability ratio that fluctuates each of its periods. Keywords: Methods of Depreciation of Fixed Assets, Accounting, Tax, Profitability
\end{abstract}

\section{PENDAHULUAN}

Setiap perusahaan memiliki aktiva tetap yang digunakan untuk menjalankan aktivitas operasional perusahaan dalam mencapai tujuan perusahaan, masalah utama dalam akuntansi aktiva tetap adalah penentuan harga perolehan, penyusutan, perlakuan terhadap pengeluaran setelah perolehan, penghapusan dan penarikan aktiva tetap serta penyajian aktiva tetap di dalam laporan keuangan perusahaan. Kesalahan perlakuan akuntansi aktiva tetap secara langsung akan mempengaruhi neraca dan perhitungan laba rugi. Karena perusahaan berkewajiban menerbitkan laporan keuangan untuk mengetahui posisi keuangan hasil usahanya kepada pihak yang bersangkutan. Dalam penerbitan laporan keuangan perusahaan harus mencantumkan semua informasi tentang metodemetode yang dipergunakan oleh perusahaan salah satunya adalah metode penyusutan aktiva tetap. 
Diperlukan pengelolaan yang efektif dan kebijakan yang berpedoman dengan SAK (Standar Akuntansi Keuangan) dalam mengelola aktiva tetap karena berpengaruh dengan aktivitas operasional perusahaan terutama perusahaan jasa penerbangan yang faktanya menggunakan banyak aktiva tetap dalam aktivitas operasionalnya.

Dalam proses penyusutan aktiva tetap ada beberapa macam metode penyusutan aktiva tetap yang bisa dipergunakan oleh perusahaan baik dari kebijakan akuntansi maupun kebijakan pajak namun perusahaan harus menggunakan metode penyusutan yang tepat, karena metode penyusutan aktiva tetap dapat mempengaruhi beban penyusutan aktiva tetap yang akan mempengaruhi perolehan laba perusahaan.

Pemakaian dan kerusakan merupakan sebab penurunan nilai ekonomis suatu aktiva tetap, sehingga perusahaan harus mampu mengestimasi biaya pemeliharaan dan reparasi. Karena itu, manajemen harus berhati-hati dalam menerapkan kebijaksanaan khususnya jumlah pengeluaran untuk aktiva tetap di atas jumlah minimal yang harus dikapitalisasi sebagai pengeluaran modal (capital expenditure) (Andy Harom: 2006).

\section{TINJAUAN PUSTAKA}

\section{II.1. Definisi Aktiva Tetap}

Menurut Standar Akuntansi Keuangan (2011 : 62) aktiva tetap adalah aset yang berwujud yang dimiliki untuk digunakan dalam produksi atau penyediaan barang atau untuk di rental kan kepada pihak lain, atau untuk tujuan administratif, dan diharapkan untuk digunakan selama lebih dari satu periode.

Menurut Hery (2014:121) "aset tetap (fixed asset) adalah aset yang secara fisik dapat dilihat keberadaannya dan sifatnya relatif permanen serta memiliki masa kegunaan (useful life) yang panjang". 


\section{II.2 Jenis-jenis Aktiva Tetap}

\section{a. Aktiva Tetap Berwujud}

Menurut Hery (2014 : 39) menyatakan bahwa aktiva tetap berwujud (tangible assets) adalah aktiva tetap yang secara fisik dapat dilihat keberadaannya dan sifatnya relatif. Permanen serta memiliki masa kegunaan (useful life) yang panjang. Istilah relatif permanen menunjukkan sifat dimana aktiva yang bersangkutan bisa digunakan dalam jangka waktu yang relatif cukup lama. Contoh dari aktiva tetap berwujud adalah tanah, bangunan, kendaraan operasional, peralatan kantor, peralatan toko, perabot kantor, dan perabot toko.

b. Aktiva Tetap Tidak Berwujud

Menurut Hery (2014 : 39) bahwa aktiva tidak berwujud (intangible assets) adalah aktiva tetap yang dimana tidak memiliki wujud fisik dan dihasilkan sebagai akibat dari sebuah kontrak hukum, ekonomi, maupun kontrak sosial. Contoh dari aktiva tetap tidak berwujud adalah goodwill (nama baik), trademark (merek dagang), franchises (waralaba), patent, copyright (hak cipta), customer list (daftar pelanggan) dan broadcast license (ijin penyiaran).

\section{c. Akuntansi Penyusutan Aktiva Tetap Berdasarkan SAK}

Standar Akuntansi Keuangan menyatakan penyusutan adalah jumlah yang bisa disusutkan dialokasikan ke setiap periode akuntansi selama masa manfaat aset tetap menggunakan berbagai metode penyusutan yang sistematis. Apapun metode penyusutan yang digunakan, diperlukan konsistensi dalam aplikasinya, tidak berubah-ubah, tanpa memandang pertimbangan pajak ataupun tingkat keuntungan perusahaan. Ini agar laporan keuangan nantinya dapat dibandingkan antara periode satu dengan periode yang lain, sebelum atau sesudahnya. Penyusutan merupakan alokasi yang sistematis dan rasional dalam membebankan biaya dan bukan merupakan pengumpulan dana untuk menggantikan aktiva tersebut. Penyusutan bukanlah teknik penilaian atas aktiva tetap melainkan suatu 
pengakuan terhadap penurunan nilai ekonomis dari suatu aktiva, Hery (2014:138).

d. Akuntansi Penyusutan Aktiva Tetap Berdasarkan Undang-Undang Perpajakan

Menurut ketentuan perpajakan (sesuai dengan pasal 11 UndangUndang PPh No. 36 tahun 2008) harta berwujud adalah harta yang disusutkan dimana harta tersebut terletak atau berada di Indonesia, yang dimiliki dan dipergunakan untuk mendapatkan, menagih, dan memelihara penghasilan yang merupakan objek pajak tidak final, serta mempunyai masa manfaat lebih dari (satu) tahun, Hery (2014:341).

1) Metode Garis Lurus khusus untuk kelompok bangunan (sesuai dengan Pasal 11 ayat 1 Undang-Undang PPh No. 36 tahun2008).

2) Metode Saldo Menurun dan Metode Garis Lurus untuk kelompok bukan bangunan, dimana pada masa akhir manfaat nilai sisa bukunya akan disusutkan sekaligus (Pasal 11 ayat 2 Undang Undang PPh No. 36 tahun 2008).

Tabel 1. Tarif Penyusutan Berdasarkan Undang-Undang Perpajakan

\begin{tabular}{|l|c|c|c|}
\hline \multirow{2}{*}{$\begin{array}{c}\text { KELOMPOK HARTA } \\
\text { BERWUJUD }\end{array}$} & $\begin{array}{c}\text { MASA } \\
\text { MANFAAT }\end{array}$ & \multicolumn{2}{|c|}{ TARIF DEPRESIASI } \\
\cline { 3 - 4 } & & GARIS LURUS & $\begin{array}{c}\text { SALDO } \\
\text { MENURUN }\end{array}$ \\
\hline \multicolumn{1}{|l}{ I. Bukan Bangunan } & \multicolumn{2}{|c|}{} \\
\hline Kelompok 1 & 4 tahun & $25 \%$ & $50 \%$ \\
\hline Kelompok 2 & 8 tahun & $12,5 \%$ & $25 \%$ \\
\hline Kelompok 3 & 16 tahun & $6,25 \%$ & $12,5 \%$ \\
\hline Kelompok 4 & 20 tahun & $5 \%$ & $10 \%$ \\
\hline II. Bangunan & & & - \\
\hline Permanen & 20 tahun & $5 \%$ & - \\
\hline Tidak Permanen & 10 tahun & $10 \%$ & \\
\hline
\end{tabular}

Sumber : http://keuanganlsm.com/penyusutan-depresiasi-menurut-perpajakan/ 


\section{II3. Perbedaan Antara Penyusutan Aktiva Tetap Dengan Menggunakan SAK Dengan Undang-Undang Perpajakan}

Dalam melakukan perhitungan penyusutan atas harta berwujud tentu saja kita perlu memperhatikan dasar penyusutan yang digunakan. Apabila dasar penyusutan yang digunakan antara akuntansi komersial dengan akuntansi pajak adalah sama (dengan asumsi menggunakan metode penyusutan serta estimasi masa manfaat yang sama), maka seharusnya besar beban penyusutan yang dihasilkan juga akan sama untuk setiap periodenya sepanjang masa manfaat dari harta berwujud bersangkutan, Hery (2014:351).

Dengan adanya pengelompokan harta berwujud berdasarkan masa manfaat dan sekaligus penetapan persentase tarif penyusutan sebagaimana yang telah diatur dalam Pasal 11 Undang-undang PPh No.36 Tahun 2008 maka hal ini dapat mengakibatkan adanya perbedaan besarnya beban penyusutan per periode antara menurut akuntansi komersial dengan akuntansi pajak. Di dalam perpajakan tidak mengenal istilah nilai sisa, berbeda dengan perlakuan yang ada dalam akuntansi komersial dimana nilai sisa dapat diperhitungkan sebagai komponen penentu besarnya beban penyusutan periodik, Hery (2014 :351).

Koreksi fiskal positif akan dilakukan apabila besarnya beban penyusutan (pada suatu periode) menurut akuntansi komersial adalah lebih besar dibandingkan beban penyusutan menurut pajak. Sebaliknya koreksi fiskal negatif akan dilakukan apabila besarnya beban penyusutan (pada satu periode) menurut akuntansi komersial adalah lebih kecil dibanding beban penyusutan menurut pajak, Hery (2014 : 351).

\section{II.4. Rasio Profitabilitas}

Rasio profitabilitas merupakan kemampuan perusahaan untuk mendapatkan laba selama periode tertentu melalui semua kemampuan dan sumber yang ada pada perusahaan seperti kegiatan penjualan, kas, modal, jumlah karyawan, jumlah cabang dan sebagainya. 


\section{HASIL PENELITIAN}

\section{Aktiva Tetap}

Tabel 2. Daftar Aktiva Tetap PT. Wijaya Karya, Tbk

\begin{tabular}{|c|c|c|c|c|c|}
\hline \multicolumn{6}{|c|}{ JENIS AKTIVA TETAP } \\
\hline \multirow{2}{*}{ Aset Pesawat } & \multicolumn{2}{|c|}{ Umur Ekonomis } & \multirow{2}{*}{ Aset Non Pesawat } & \multicolumn{2}{|c|}{ Umur Ekonomis } \\
\hline & $2009-2012$ & $2013-2014$ & & $2009-2012$ & $2013-2014$ \\
\hline Pemilikan Langsung & & & Pemilikan Langsung & & \\
\hline Rangka Konstruksi & $18-20$ & $18-22$ & Perlengkapan \& peralatan & $2-10$ & $2-10$ \\
\hline Mesin & $18-20$ & $18-22$ & Perangkat keras & $2-10$ & $2-10$ \\
\hline Simulator & 10 & 10 & Kendaraan & $3-5$ & $3-5$ \\
\hline Rotable parts & 12 & 12 & Mesin & $18-20$ & $18-22$ \\
\hline Aset pemeliharaan & & +2 & Instalasi & $2-10$ & $2-10$ \\
\hline Rangka Konstruksi & $18-20$ & $18-22$ & Tanah & - & - \\
\hline Mesin & $18-20$ & $18-22$ & Bangunan \& prasarana & 40 & 40 \\
\hline Aset dalam penyelesaian & +2 & & Aset dalam penyelesaian & $2-10$ & $2-10$ \\
\hline Aset sewa pembiayaan & +2 & & Aset sewa & & \\
\hline Rangka konstruksi & $18-20$ & $18-22$ & Kendaraan & $3-5$ & $3-5$ \\
\hline Pengembangan aset sewa & & & Bangun, kelola, alih & & \\
\hline Mesin & $18-20$ & $18-22$ & Bangunan \& prasarana & 40 & 40 \\
\hline & & & Mesin & $18-20$ & $18-22$ \\
\hline 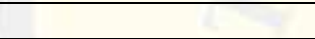 & 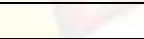 & & Instalasi & $2-10$ & $2-10$ \\
\hline
\end{tabular}

Sumber: $\quad$ Data diolah dari laporan keuangan PT. Wijaya Karya, Tbk Periode 2014-2019

\section{Kebijakan Perusahaan dalam Mengelola Aktiva Tetap}

Adapun kebijakan perusahaan dalam mengelola penyusutan aktiva tetap adalah sebagai berikut:

1. Aset tetap Mesin Konstruksi disusutkan hingga ke estimasi nilai residu dengan menggunakan metode garis lurus selama taksiran masa manfaat. Aset tetap non mesin kecuali tanah dan bangunan dicatat berdasarkan harga perolehan dikurangi akumulasi penyusutan dan penurunan nilai, jika ada dan disusutkan dengan metode garis lurus selama masa manfaat aset tersebut.

2. Aset sewaan disusutkan berdasarkan taksiran masa manfaat ekonomis yang sama dengan aset tetap yang dimiliki sendiri atau disusutkan selama jangka waktu yang lebih pendek antara periode sewa dan umur manfaatnya.

3. Aset dalam penyelesaian dinyatakan sebesar biaya perolehan. Biaya perolehan tersebut termasuk biaya pinjaman yang terjadi selama masa pembangunan yang timbul dari utang yang digunakan untuk pembangunan aset tersebut. Akumulasi biaya perolehan akan 
dipindahkan ke masing-masing aset tetap yang bersangkutan pada saat selesai dan siap digunakan.

4. Aset tetap dalam rangka bangun, kelola dan alih dinyatakan berdasarkan biaya perolehan setelah dikurangi akumulasi penyusutan. Penyusutan dihitung dengan menggunakan metode garis lurus selama 20 - 30 tahun.

5. Tanah tidak disusutkan karena memiliki masa manfaat yang tidak terbatas.

\section{Penyusutan Menurut Kebijakan Akuntansi dan Pajak}

Penyusutan menurut kebijakan akuntansi dan pajak adalah sebagai berikut:

Tabel 3. Penyusutan Menurut Kebijakan Akuntansi Dan Pajak

\begin{tabular}{cccc} 
& & (dalam jutaan rupiah) \\
\hline Tahun & Kebijakan Akuntansi & \multicolumn{3}{c}{ Kebijakan Pajak } \\
\hline 2014 & $\mathrm{Rp} 1.595 .479$ & $\mathrm{Rp}$ & 365.576 \\
\hline 2015 & $\mathrm{Rp} 1.634 .198$ & $\mathrm{Rp}$ & 355.103 \\
\hline 2016 & $\mathrm{Rp} 1.096 .709$ & $\mathrm{Rp}$ & 61.449 \\
\hline 2017 & $\mathrm{Rp} 1.256 .680$ & $\mathrm{Rp}$ & 169.707 \\
\hline 2018 & $\mathrm{Rp} 1.876 .052$ & $\mathrm{Rp}$ & 218.627 \\
\hline 2019 & $\mathrm{Rp} 2.378 .262$ & $\mathrm{Rp}$ & 153.811 \\
\hline Jumlah & $\mathrm{Rp} 9.837 .382$ & $\mathrm{Rp}$ & 1.324 .274 \\
Sumber: & Data diolah dari laporan keuangan PT. Wijaya Karya, Tbk periode \\
& 2014-2019 & &
\end{tabular}

Koreksi Perhitungan Penyusutan Aktiva Tetap Menurut Kebijakan

\section{Akuntansi dan Pajak}

Laporan keuangan yang disusun oleh PT. Wijaya Karya, Tbk merupakan laporan keuangan komersial yang berpedoman dengan SAK (Standar Akuntansi Keuangan), sehingga terdapat perbedaan yang signifikan dengan kebijakan perpajakan yang berpedoman terhadap undang-undang perpajakan sehingga perlu dilakukan koreksi. Perbedaan laba disajikan sebagai berikut: 
Tabel 4. Perbedaan Laba Menurut Kebijakan Akuntansi Dan Pajak

(dalam jutaan rupiah)

\begin{tabular}{ccc}
\hline Tahun & Kebijakan Akuntansi & Kebijakan Pajak \\
\hline 2014 & $R p \quad 876.099$ & $R p ~ 2.106 .002$ \\
\hline 2015 & $R p \quad 411.445$ & $R p ~ 1.690 .540$ \\
\hline 2016 & $R p 1.002 .657$ & $R p 2.160 .815$ \\
\hline 2017 & $R p 1.465 .300$ & $R p ~ 2.552 .273$ \\
\hline 2018 & $R p \quad 166.425$ & $R p ~ 1.823 .850$ \\
\hline 2019 & $R p(5.729 .092)$ & $R p(3.504 .641)$ \\
\hline Jumlah & $R p 9.651 .019$ & $R p ~ 6.828 .840$ \\
\hline Sumber: & Data diolah dari laporan keuangan PT. Wijaya Karya, Tbk periode \\
& 2014-2019
\end{tabular}

Adanya perbedaan yang signifikan antara perhitungan penyusutan menurut kebijakan akuntansi dengan perhitungan penyusutan menurut kebijakan pajak menghasilkan perbedaan laba yang dihasilkan, sehingga perlu adanya koreksi fiskal untuk menyesuaikan laba menurut kebijakan akuntansi yang berbeda dengan ketentuan pajak. Tidak selalu laba menurut kebijakan akuntansi akan menjadi lebih kecil dibandingkan dengan laba menurut kebijakan pajak setelah melakukan koreksi fiskal, hal tersebut dikarenakan ada biaya yang diakui dalam laporan keuangan komersial yang dikategorikan sebagai pengeluaran, namun bukan merupakan kategori biaya menurut ketentuan pajak.

Tabel 5. Koreksi Fiskal Atas Beban Penyusutan Tahun 2014

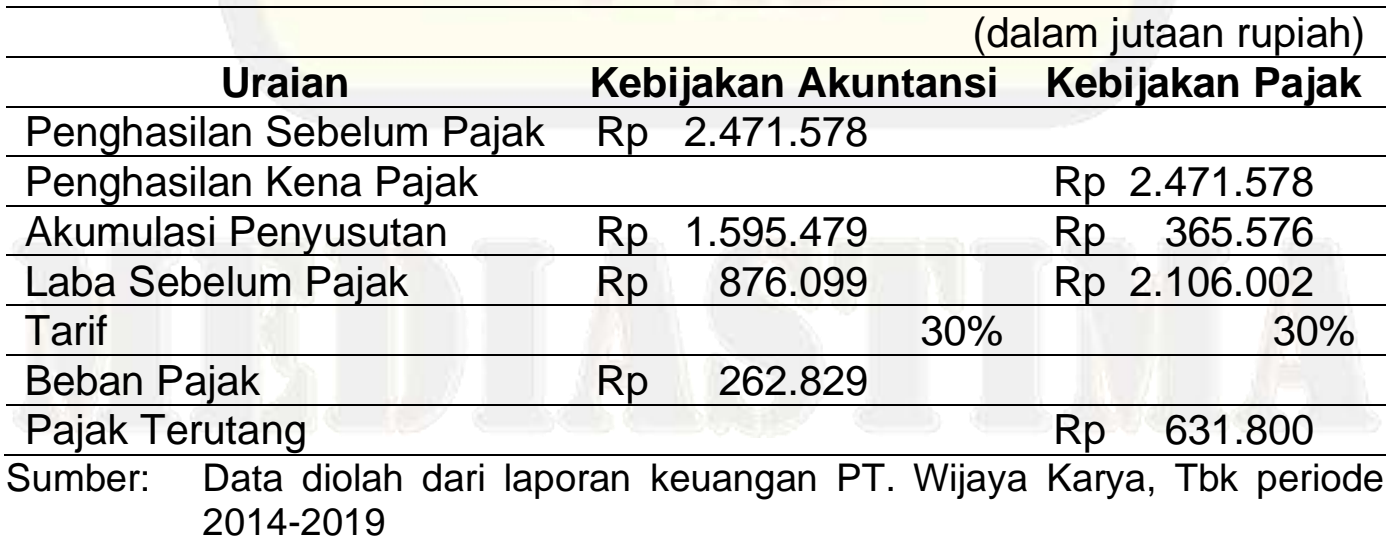


Tabel 6. Koreksi Fiskal Atas Beban Penyusutan Tahun 2015

(dalam jutaan rupiah)

\begin{tabular}{|c|c|c|}
\hline Uraian & Kebijakan Akuntansi & Kebijakan Pajak \\
\hline Penghasilan Sebelum Pajak & $\operatorname{Rp} 2.045 .643$ & \\
\hline Penghasilan Kena Pajak & & Rp 2.045.643 \\
\hline Akumulasi Penyusutan & Rp 1.634 .198 & Rp $\quad 355.103$ \\
\hline Laba Sebelum Pajak & 411.445 & Rp 1.690 .540 \\
\hline Tarif & $30 \%$ & $30 \%$ \\
\hline Beban Pajak & 123.433 & \\
\hline Pajak Terutang & & 507.162 \\
\hline
\end{tabular}

Tabel 7. Koreksi Fiskal Atas Beban Penyusutan Tahun 2016

(dalam ribuan rupiah)

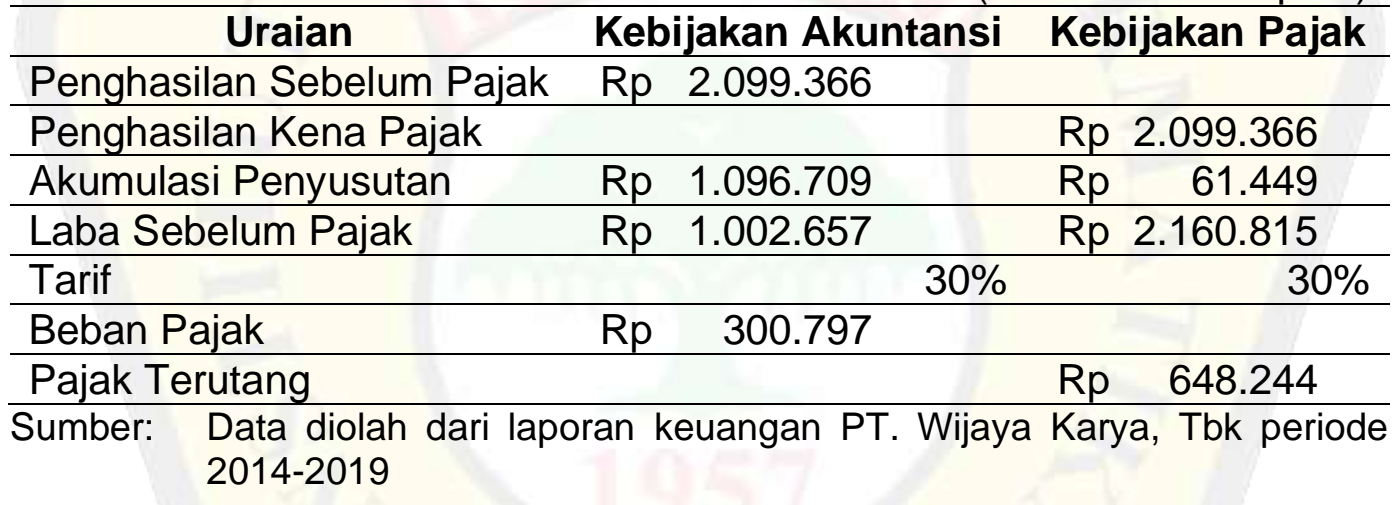

Tabel 8. Koreksi Fiskal Atas Beban Penyusutan Tahun 2017

(dalam jutaan rupiah)

\begin{tabular}{|c|c|c|}
\hline Uraian & Kebijakan Akuntansi & Kebijakan Pajak \\
\hline Penghasilan Sebelum Pajak & Rp 2.721.981 & \\
\hline Penghasilan Kena Pajak & & Rp 2.721.981 \\
\hline Akumulasi Penyusutan & Rp 1.256 .680 & $\begin{array}{ll}\mathrm{Rp} & 169.707 \\
\end{array}$ \\
\hline Laba Sebelum Pajak & Rp 1.465 .300 & Rp 2.552.273 \\
\hline Tarif & $30 \%$ & $30 \%$ \\
\hline Beban Pajak & 439.590 & \\
\hline Pajak Terutang & & 765.682 \\
\hline $\begin{array}{ll}\text { Sumber: } & \text { Data diolah dari la } \\
& 2014-2019\end{array}$ & & \\
\hline
\end{tabular}


Tabel 9. Koreksi Fiskal Atas Beban Penyusutan Tahun 2018

(dalam jutaan rupiah)

\begin{tabular}{|c|c|c|}
\hline Uraian & Kebijakan Akuntansi & Kebijakan Pajak \\
\hline Penghasilan Sebelum Pajak & Rp 2.042.477 & \\
\hline Penghasilan Kena Pajak & & Rp2.042.477 \\
\hline Akumulasi Penyusutan & Rp 1.876.052 & Rp 218.627 \\
\hline Laba Sebelum Pajak & Rp 166.425 & Rp1.823.850 \\
\hline Tarif & $30 \%$ & $30 \%$ \\
\hline Beban Pajak & 49.927 & \\
\hline Pajak Terutang & & Rp 547.155 \\
\hline
\end{tabular}

Tabel 10. Koreksi Fiskal Atas Beban Penyusutan Tahun 2019

(dalam jutaan rupiah)

\begin{tabular}{|c|c|c|}
\hline Uraian & Kebijakan Akuntansi & Kebijakan Pajak \\
\hline Penghasilan Sebelum Pajak & $\operatorname{Rp}(3.350 .829)$ & \\
\hline Penghasilan Kena Pajak & & $\mathrm{Rp}(3.350 .829)$ \\
\hline Akumulasi Penyusutan & Rp 2.378 .262 & Rp 153.811 \\
\hline Rugi Sebelum Pajak & $\operatorname{Rp}(5.729 .092)$ & $\operatorname{Rp}(3.504 .641)$ \\
\hline Tarif & $30 \%$ & $30 \%$ \\
\hline Beban Pajak & - & 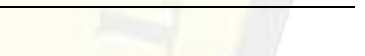 \\
\hline Pajak Yang Dikompensasi & & $(1.051 .392)$ \\
\hline $\begin{array}{ll}\text { Sumber: } & \text { Data diolah dari la } \\
& 2014-2019\end{array}$ & & Karya, Tbk perio \\
\hline
\end{tabular}

\section{Rasio Profitabilitas}

Berdasarkan data dan hasil penelitian mengenai metode penyusutan aktiva tetap yang berdasarkan kebijakan akuntansi dan kebijakan pajak yang telah dilakukan pada PT. Wijaya Karya menghasilkan tingkat profitabilitas sebagai berikut:

Tabel 11. Tingkat Rasio Profitabilitas

\begin{tabular}{ccccccc}
\hline \multirow{2}{*}{ Rasio (\%) } & $\mathbf{7}$ Tahun \\
\cline { 2 - 7 } & $\mathbf{2 0 1 4}$ & $\mathbf{2 0 1 5}$ & $\mathbf{2 0 1 6}$ & $\mathbf{2 0 1 7}$ & $\mathbf{2 0 1 8}$ & $\mathbf{2 0 1 9}$ \\
\hline ROA & 5,92 & 0,56 & 4,49 & 4,40 & 0,38 & $-1,5$ \\
\hline ROE & 2,80 & 8,47 & 10,71 & 9,94 & 1,00 & $-4,1$ \\
\hline NPM & 1,13 & 1,76 & 2,98 & 3,19 & 0,30 & $-0,9$ \\
\hline
\end{tabular}

Sumber: Data diolah dari laporan keuangan PT. Wijaya Karya, Tbk periode 2014-2019 


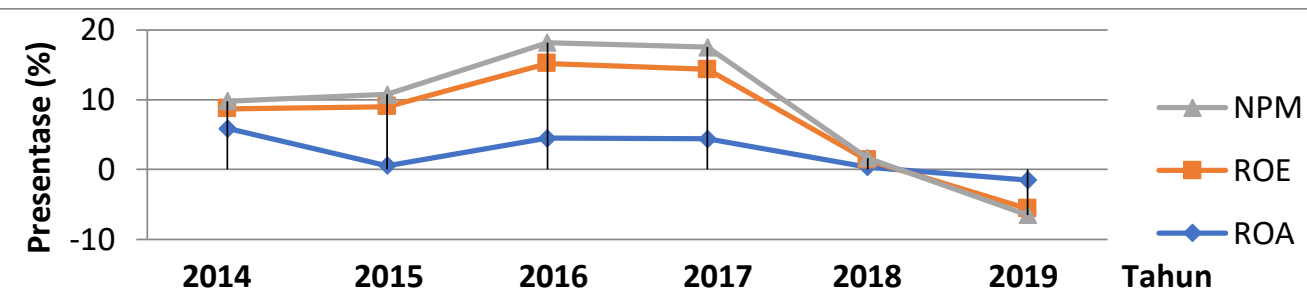

Grafik 3. Rasio Profitabilitas PT. Garuda Indonesia, Tbk Periode 2009 - 2014

Sumber: Data diolah dari laporan keuangan PT. Garuda Indonesia, Tbk periode 2009-2014

\section{Rasio ROA}

Bentuk dari rasio profitabilitas untuk mengukur kemampuan perusahaan dalam menghasilkan laba menggunakan total aktiva dan laba / rugi setelah pajak.

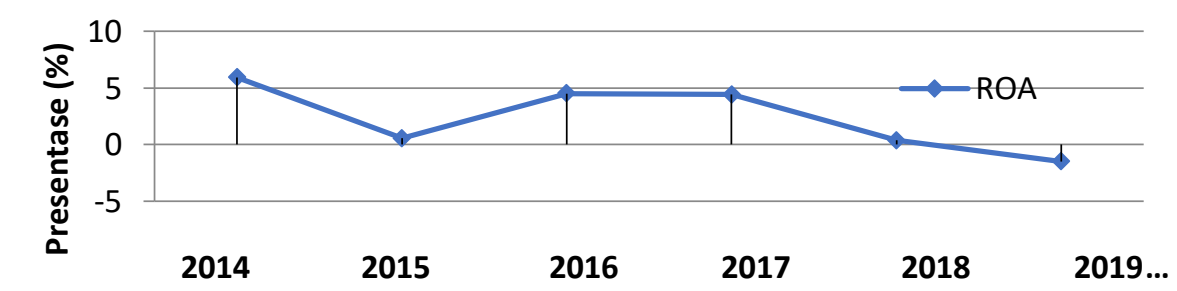

Grafik 4. Rasio ROA PT. Wijaya Karya, Tbk Periode 2014 - 2019

Sumber: Data diolah dari laporan keuangan Wijaya Karya, Tbk periode 2014-2019

Rasio ROA PT. Wijaya Karya, Tbk menunjukkan ROA yang positif dari periode 2014 sampai 2019 hal tersebut dapat diartikan bahwa dari total aktiva yang digunakan untuk operasi perusahaan mampu memberikan laba bagi perusahaan dan sebaliknya untuk periode 2019 menunjukkan ROA yang negatif, dari total aktiva yang digunakan untuk operasi perusahaan tidak mampu memberikan laba bagi perusahaan. 


\section{Rasio ROE}

Rasio Return On Equity (ROE) ini merupakan indikator yang digunakan untuk mengukur kemampuan perusahaan dalam memperoleh laba bersih yang dibandingkan dengan total ekuitas.

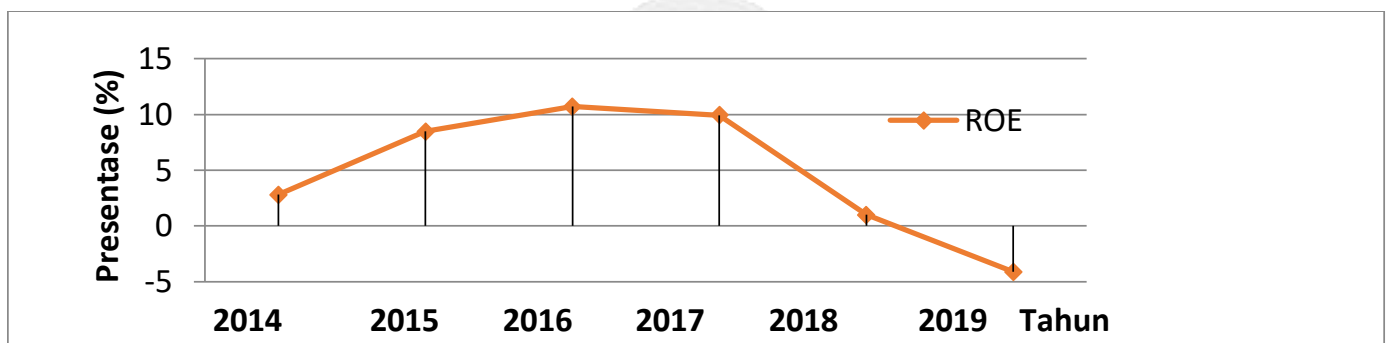

Grafik 5. Rasio ROE PT. Wijaya Karya, Tbk Periode 2014 - 2019

Sumber: Data diolah dari laporan keuangan Wijaya Karya, Tbk periode 2014-2019

Dapat dilihat dari grafik di atas pada periode 2014 - 2015 dan periode 2015 - 2016 mengalami kenaikan rasio ROE secara berturut - turut sebesar 5,67 dan 2,24 persen, hal ini menyebabkan kenaikan harga saham perusahaan, karena semakin tinggi ROE semakin baiknya kinerja perusahaan dalam mengelola modal untuk menghasilkan laba. Dengan adanya peningkatan laba bersih maka nilai ROE akan meningkat pula, hal ini memberi indikasi bahwa jika pengembalian yang akan diterima investor akan tinggi sehingga dapat menarik investor untuk membeli saham perusahaan yang berdampak terhadap kenaikan harga saham perusahaan. Keadaan tersebut berbanding terbalik di periode 2016 - 2017, 2017 - 2018 dan 2018 - 2019 yang mengalami penurunan secara berturut - turut sebesar $0,77,8,94$ dan 3,1, hal ini menggambarkan bahwa semakin menurunnya kinerja perusahaan dalam mengelola modalnya untuk menghasilkan laba.

\section{Rasio NPM}

Rasio Net profit margin (NPM) menggambarkan tingkat keuntungan (laba) yang diperoleh perusahaan dibandingkan dengan pendapatan yang 
dihasilkan dari kegiatan operasional. Semakin tingginya rasio NPM maka semakin baiknya kinerja perusahaan dalam mendapatkan laba bersih melalui aktivitas operasional perusahaan.

Keadaan ini terjadi pada periode tahun 2014 sampai 2017 yang menggambarkan nilai rasio NPM terus meningkat hingga diangka 3,19\%, namun pada periode 2018 sampai 2019 nilai rasio NPM mengalami penurunan sebesar $0,6 \%$ yang berarti menurunnya kinerja perusahaan dalam menghasilkan laba bersih yang diperoleh dari aktivitas operasional perusahaan.

\section{PEMBAHASAN HASIL PENELITIAN}

Berdasarkan hasil penelitian, penulis menginterpretasikan bahwa:

1. Perubahan masa manfaat hanya berdampak berkurangnya nilai beban penyusutan, namun ditinjau secara keseluruhan perubahan masa manfaat tersebut tidak berpengaruh terhadap akumulasi penyusutan dan laba bersih yang diperoleh oleh perusahaan, hal ini dapat terlihat bahwa setiap periode tingkat beban penyusutan dan laba selalu berfluktuasi.

2. Perolehan aktiva tetap melalui capital lease dan operating lease. PT. Wijaya Karya lebih banyak memperoleh aktiva tetapnya melalui sewa operasi daripada sewa pembiayaan, hal ini berdampak terhadap menekan beban penyusutan yang seharusnya menjadi beban perusahaan karena beban penyusutan aktiva tetap yang diperoleh melalui sewa operasi tidak dibebankan kepada PT. Wijaya Karya, Tbk melainkan dibebankan kepada pihak lessor sehingga beban penyusutan lebih aktiva tetap yang diperoleh melalui sewa pembiayaan lebih besar dibandingkan beban penyusutan aktiva tetap yang diperoleh melalui sewa operasi.

3. Adanya perbedaan antara ketentuan Standar Akuntansi Keuangan dan ketentuan pajak menimbulkan perhitungan metode penyusutan yang berbeda, hal tersebut merupakan faktor yang mempengaruhi besarnya 
beban penyusutan dan laba yang berbeda. Perbedaan tersebut menghasilkan penetapan pengenaan pajak penghasilan akan berbeda antara nominal yang tercantum dengan surat pemberitahuan pajak tahunan dengan pemeriksaan yang dilakukan oleh pihak pajak, hal ini disebabkan adanya biaya-biaya yang diakui dalam laporan keuangan komersial yang dikelompokkan sebagai biaya, akan tetapi menurut fiskal bukan merupakan biaya dan jika hal tersebut tidak dikelola dengan efisien maka perusahaan akan dikenakan sanksi yang berupa denda administratif. Sehingga perusahaan harus membuat rekonsiliasi fiskal untuk menentukan nominal laba kena pajak sehingga diperoleh pajak terutang pada tahun yang bersangkutan.

4. Rasio profitabilitas PT. Wijaya Karya berfluktuasi. Untuk nilai ROA positif dari periode 2014 sampai 2018 hal tersebut menggambarkan bahwa dari total aktiva yang digunakan untuk operasi perusahaan mampu memberikan laba bagi perusahaan dan sebaliknya untuk periode 2019 menunjukkan ROA yang negatif. Untuk nilai ROE pada periode 2014 2015 dan periode 2015 - 2016 mengalami kenaikan rasio ROE secara berturut - turut sebesar 5,67 dan 2,24 persen, hal ini menunjukkan bahwa semakin meningkatnya kinerja perusahaan dalam mengelola modalnya untuk mendapatkan laba, namun kinerja perusahaan dalam mendapatkan laba dengan modalnya menurun di periode 2016 - 2017, 2017 - 2018, dan 2018 - 2019 sebesar 0,77 \%, 8,94\% dan 3,1\%. Untuk nilai NPM terus meningkat hingga diangka 3,19\%, namun pada periode 2018 sampai 2019 nilai rasio NPM mengalami penurunan sebesar 0,6\% yang berarti menurunnya kinerja perusahaan dalam menghasilkan laba bersih yang diperoleh dari aktivitas operasional perusahaan.

5. Sebagai perusahaan besar memerlukan dana serta biaya dan investasi yang cukup besar dengan melibatkan pelanggan ataupun kreditur baik dalam maupun luar negeri dengan kondisi dimana transaksi dicatat berdasarkan satuan mata uang. Pergerakan nilai tukar non-fungsional terhadap mata uang yang lainnya sangat mempengaruhi laporan 
keuangan. Kebijakan perusahaan dalam mengatasi risiko nilai tukar adalah dengan memanfaatkan nilai tukar mata uang lainnya untuk menutup kemungkinan pada resiko melemahnya nilai tukar fungsional dan sebaliknya dan menyelaraskan penerimaan dan pembayaran untuk setiap jenis mata uang.

\section{PENUTUP}

\section{V.1. Kesimpulan}

Berdasarkan data dan hasil penelitian mengenai metode penyusutan aktiva tetap yang berdasarkan kebijakan akuntansi dan kebijakan pajak yang telah dilakukan pada PT. Wijaya Karya, Tbk, maka dapat disimpulkan bahwa:

1. PT. Wijaya Karya telah mengelola aktiva tetap secara efektif dan efisien menggunakan metode penyusutan garis lurus yang sesuai dengan Pernyataan Standar Akuntansi Keuangan, namun tidak konsisten dalam penerapan dan pelaksanaannya dari periode ke periode berikutnya, hal ini dikarenakan perusahaan mengubah masa manfaat aset yang dimilikinya.

2. Berdasarkan perhitungan penyusutan aktiva tetap menurut kebijakan akuntansi dan kebijakan pajak menghasilkan beban penyusutan yang berbeda sehingga menghasilkan laba berbeda, yang disebabkan oleh perbedaan kebijakan masa manfaat, metode penyusutan dan adanya biaya-biaya yang diakui dalam laporan keuangan komersial yang dikelompokkan sebagai biaya, akan tetapi menurut fiskal bukan merupakan biaya.

3. PT. Wijaya Karya, Tbk memperoleh aktiva tetap lebih banyak melalui operating lease daripada capital lease hal ini akan meringankan beban penyusutan karena beban penyusutan aktiva tetap yang diperoleh melalui sewa operasi tidak dibebankan kepada perusahaan melainkan dibebankan kepada pihak lessor sehingga beban penyusutan lebih 
aktiva tetap yang diperoleh melalui sewa pembiayaan lebih besar dibandingkan beban penyusutan aktiva tetap yang diperoleh melalui sewa operasi.

4. Terdapat perbedaan antara kebijakan penyusutan Standar Akuntansi Keuangan dan ketentuan pajak yang akan menimbulkan perhitungan metode penyusutan, besarnya beban penyusutan, laba yang dihasilkan berbeda. Sehingga perusahaan harus merekonsiliasi fiskal untuk menentukan besarnya pajak terutang pada periode yang bersangkutan.

5. Berdasarkan data dan hasil penelitian mengenai metode penyusutan aktiva tetap yang berdasarkan kebijakan akuntansi dan kebijakan pajak yang telah dilakukan pada PT. Wijaya Karya tingkat rasio profitabilitas mengalami fluktuasi.

\section{V.2. Saran}

1. Harus dijaga kekonsistenannya dalam mengelola aktiva tetap berdasarkan Pernyataan Standar Akuntansi Keuangan, karena PT. Wijaya Karya tidak konsisten dalam mengelola aktiva tetapnya dengan merubah masa manfaat 2 aset yang dimilikinya.

2. Dikarenakan adanya perbedaan antara laba menurut akuntansi dan fiskal perusahaan harus membuat rekonsiliasi fiskal untuk menetapkan penghasilan kena pajak dan menghitung pajak terutang sehingga perusahaan tidak perlu membuat laporan keuangan ganda (laporan keuangan komersial dan fiskal).

3. Adakan evaluasi secara berkala mengenai bidang usaha dalam meningkatkan dan mempertahankan laba dan tingkat profitabilitas karena semakin baiknya tingginya tingkat profitabilitas perusahaan maka semakin baiknya kinerja perusahaan dalam mendapatkan laba baik dengan aktiva, modal, dan pendapatan operasional perusahaan. 


\section{DAFTAR PUSTAKA}

Bustami Bastian, Nurlela 2012 "Akuntansi Biaya”, Mitra Wancana Media, Jakarta.

Horngren Charles T, Harrison Walter T 2007 "Akuntansi", Erlangga, Jakarta.

Jusup Al Ariyono 2005 “Dasar-Dasar Akuntansi” STIE YKPN, Yogyakarta.

Kartikahadi Hans, Sinaga Rosita Uli, Syamsul, Merliyana, Siregar Sylvia Vernica 2012 "Akuntansi Keuangan Berdasarkan SAK Berbasis IFRS", Salemba Empat, Bandung.

Kieso Donal E, Weygandt Jerry J, Warfield Terry D 2008 "Akuntansi Intermediate", Edisi ke Dua Belas, Erlangga, Jakarta.

Martiani Dwi, Veronica NPS Sylvia, Wardani Ratna 2012 "Akuntansi Keuangan Menengah Berbasis PSAK", Salemba Empat, Jakarta.

Stice Earl, Stice James, Skousen K Fred 2005 "Intermediate Accounting" Salemba Empat, Jakarta.

Stice James, Stice Earl, Skousen K Fred 2009 "Akuntansi Keuangan", Salemba Empat, Jakarta.

Syakur Ahmad Syafi'i 2009 "Intermediate Accounting Dalam Perspektif Lebih Luas", AV Publisher Jakarta-Indo, Jakarta.

Warren Carls, Reeve James, Fees Philip 2006 "Accounting Pengantar Akuntansi", Salemba Empat, Jakarta.

Weygandt Jerry J, Kieso Donal E, Kimmel Paul D 2009 "Accounting Priniples Pengantar Akuntansi”, Salemba Empat, Jakarta.

http://www.idx.go.id

http://www.bi.go.id

http://www.bps.go.id

http://www.sahamok.com 